\title{
Restoration of woodpasture on former agricultural land: The importance of safe sites and time gaps before grazing for tree seedlings
}

\author{
Jan Van Uytvanck ${ }^{a, *}$, Dirk Maes ${ }^{a}$, Dominique Vandenhaute ${ }^{b}$, Maurice Hoffmann ${ }^{a, b}$ \\ ${ }^{a}$ Research Institute for Nature and Forest, Kliniekstraat 25, B-1070 Brussels, Belgium \\ ${ }^{b}$ Terrestrial Ecology Unit, Department of Biology, Ghent University, K.L. Ledeganckstraat 35, B-9000 Ghent, Belgium
}

\section{A R T I C L E I N F O}

\section{Article history:}

Received 2 April 2007

Received in revised form

7 September 2007

Accepted 12 September 2007

Available online 24 October 2007

Keywords:

Associational resistance

Conservation management

Low intensity grazing

Large herbivores

Tree regeneration

\begin{abstract}
A B S T R A C T
Woodpastures (open, grazed woodlands with a mosaic of grassland, shrub and tree patches) are of high biological and cultural value and have become a threatened ecosystem in Europe. Spontaneous tree regeneration in the presence of large herbivores, is an essential process for management and restoration of this structurally diverse habitat. We examined the suitability of five vegetation types (grasslands, ruderal vegetations, tall sedges, rush tussocks and bramble thickets), grazed by large herbivores, for tree regeneration. We hypothesized that bramble thickets and tall herb communities operate as safe sites for palatable tree species through the mechanism of associational resistance. We set up a field experiment with tree seedlings in grazed and ungrazed conditions and recorded mortality and growth of seedlings of two palatable tree species (Quercus robur and Fraxinus excelsior) during three growing seasons. In the same experiment, we studied the effect of a two year's initial time gap before grazing.

Bramble thickets were suitable safe sites for survival and growth of seedlings of both species. Tall sedges, soft rush tussocks and ruderal vegetations with unpalatable or spiny species provided temporal protection, allowing seedlings to survive. Tree regeneration in livestock grazed grassland was highly constrained. Rabbits may undo the nursing effects of bramble thickets. The first year's survival is of major importance for the establishment of trees. Subsequent grazing affects growth rather than survival. A two year's initial time gap before grazing, had positive effects on survival, but did not enhance outgrowth of unprotected trees.
\end{abstract}

(c) 2007 Elsevier Ltd. All rights reserved.

\section{Introduction}

Woodpastures are the product of a low intensity, often historical land use. Conservation values are high and include different species-rich vegetation types of heaths, wetlands, seminatural grasslands, edge, bush and woodland communities
(Pott and Hüppe, 1991). Woodpastures are found throughout Europe and represent a vegetation structure, rather than being a particular plant community confined to a certain region. This vegetation structure consists of open woodland with scattered trees or forest patches in a matrix of grassland, tall grasses and shrubs (or heather). Large herbivores are part

\footnotetext{
* Corresponding author: Tel.: +32 0255818 64; fax: +32 025581805 .

E-mail addresses: jan.vanuytvanck@inbo.be (J. Van Uytvanck), dirk.maes@inbo.be (D. Maes), c.vdhaute@skynet.be (D. Vandenhaute), maurice.hoffmann@inbo.be (M. Hoffmann). 0006-3207/\$ - see front matter @ 2007 Elsevier Ltd. All rights reserved. doi:10.1016/j.biocon.2007.09.001
} 
and parcel of the system, which is maintained by grazing. Healthy woodpastures should have a wide range of tree ages within them to ensure they survive in the future (Quelch, 2001).

Since the beginning of agriculture in the Neolithic period, woodpasture has been the major form of woodland utilisation in Europe. Vera (2000) considers that this park-like landscape may be much older as a result of the natural interaction between wild large herbivores and vegetation development. Nowadays only remnants are left though, e.g. the New Forest in England and Börkener Paradies in Germany (Tubbs, 1986; Pott and Hüppe, 1991). On a smaller scale, woodpasture practices are maintained in the Alpine region in Austria, the Swiss and French Jura, the Vosges and the Massif Central in France and the dehesa ecosystems in Central-West Spain (Humphrey et al., 1998; Smit et al., 2006) or in nature reserves (e.g. JunnerKoeland in the Netherlands and a number of smaller remnants in Southern Scandinavia and the UK). In this respect, remnant woodpastures are not only important for their high biological values (Tubbs, 1986; Vera, 2000), they also represent landscape types with a high cultural-historical value (Rozas, 2004; Manning et al., 2006). Heterogeneity in vegetation structure is an intrinsic feature of well developed woodpastures (Rosen and Bakker, 2005) and is often linked with high floral and fauna biodiversity (Olff and Ritchie, 1998; van Wieren, 1998; Dennis et al., 1998).

The management of woodpastures has been characterised by low intensity grazing by domesticated herbivores, but other land use practices such as logging, coppicing, pollarding, hay-making, litter-collection and burning were also part of the management (Pott, 1998; Bakker and Londo, 1998). Despite this large variety of management measures, spontaneous regeneration of woody species seems not to be completely prevented. Understanding the operating mechanisms that lead to the typical vegetation and regeneration patterns is important with regard to conservation and restoration of woodpastures and the creation of comparably structured pastures today.

Recently, several efforts were made to restore or create woodpasture systems for conservation purposes in a broad range of nature reserves in Flanders (N-Belgium). In particular, former agricultural land, adjacent to existing nature reserves or forests, is often incorporated in restoration projects to create mosaic vegetations, with continuous gradients of open, half open to closed habitat types, i.e. from grasslands to forests. In the 1980s, this landscape type, with vegetation mosaics and continuous gradients, became a new frame of reference for conservation management in the Netherlands (Bakker and Londo, 1998) and subsequently in the rest of Europe.

High stocking rates, as well as total abandonment may lead to a loss of spatial heterogeneity, and hence biodiversity (Kirby et al., 1995). A better understanding of the process of tree regeneration in grazed ecosystems is therefore essential for the continuation of a system that balances between suppression of woodland regeneration and succession towards closed woodland. In particular, little is known about shrub and tree regeneration under low-intensity grazing in restoration projects on former agricultural land (Olff et al., 1999). These early stages are important as they may determine the species composition and pattern of mid- and late-successional trees (Davidson, 1993).

The key processes to be understood in grazed ecosystems which include woodland are plant strategies in coping with herbivory, herbivore selectivity and light requirements (Olff et al., 1999).

Olff et al. (1999) presented a descriptive model of longterm cyclic succession, in which free ranging herbivores and alternating associational resistance and competition, play a crucial role. A core assumption in this model is that unpalatable, thorny or spiny shrub species create safe sites for the establishment of palatable tree species in a palatable grassland matrix. In a next stage, light demanding shrubs gradually disappear due to competition with growing trees. In a last stage, gaps created by falling trees, enable the re-establishment of grassland. Spatial asynchronisation of this cyclic mechanism causes shifting mosaics with patches of all structural vegetation types involved. Evidence for these succession mechanisms in the initial stages is accumulating (e.g. Callaway and Davis, 1998; Callaway et al., 2000; Bokdam and Gleichman, 2000; Rousset and Lepart, 2003; Bossuyt et al., 2005), although experimental work is rather sparse (Callaway et al., 2005; Callaway, 1992; Rousset and Lepart, 2000; Bakker et al., 2004; Smit et al., 2006).

As an alternative to associational resistance, temporal removal of large herbivores (either due tot a management decision or a natural crash in the herbivore population) may create a window of opportunity for woody species to establish (Peterken and Tubbs, 1965; Olff et al., 1999; Mountford and Peterken, 2003). Short time gaps (1-2 years) before grazing management often occur after cessation of agricultural use and before the start of conservation management. This may be the result of practical regulations or a carefully thoughtout measure to trigger succession and tree regeneration. However, the effects of such initial time gaps before grazing are poorly researched.

In this study, we focus on the initial stages of the establishment of woody species (mortality and growth of palatable tree seedlings of Quercus robur and F. excelsior) in grazed nature reserves on former agricultural land (no tree regeneration present before the start of conservation management). In general, we explore the interactions between grazing, time gaps and structurally different vegetation types in a broad geomorphological range on nutrient rich soils. We hypothesize that bramble thickets and tall herb communities act as safe sites during the establishment phase. We hypothesize that time gaps before grazing offer significant advantages to seedling survival and growth.

\section{Methods}

\subsection{Study sites}

We selected four nature reserves on former agricultural land for a field experiment in the southern part of Flanders (N-Belgium). Boelaremeersen and Rietbeemd are situated in the floodplains of the Dender basin and Bos t' Ename and Steenbergbos are situated on the drier slopes of interfluvial zones (Table 1). The former land use consisted of cattle breeding 


\section{Table 1 - Study site characteristics}

\begin{tabular}{|c|c|c|c|c|c|c|c|c|c|c|c|c|c|c|c|c|}
\hline \multirow{2}{*}{$\begin{array}{l}\text { Study site } \\
\text { Coordinates and size (ha) }\end{array}$} & \multicolumn{4}{|c|}{ Boelaremeersen } & \multicolumn{4}{|c|}{ Rietbeemd } & \multicolumn{4}{|c|}{ Bos t'Ename } & \multicolumn{4}{|c|}{ Steenbergbos } \\
\hline & & \multicolumn{2}{|c|}{$50^{\circ} 75^{\prime} \mathrm{N}-3^{\circ} 88^{\prime} \mathrm{E}$} & \multicolumn{2}{|l|}{22.1} & \multicolumn{2}{|c|}{$50^{\circ} 86^{\prime}-3^{\circ} 65 \mathrm{E}$} & \multicolumn{2}{|l|}{39.5} & \\
\hline Grazing type & \multicolumn{4}{|c|}{ Seasonal (May-October) } & \multicolumn{4}{|c|}{ Year round } & \multicolumn{4}{|c|}{ Year round } & \multicolumn{4}{|c|}{ Seasonal (May-October) } \\
\hline Starting year grazing management & 2001 & & & & \multirow{2}{*}{\multicolumn{4}{|c|}{$\begin{array}{l}1997 \\
\text { Cattle + horses }(0.4)\end{array}$}} & \multirow{2}{*}{\multicolumn{4}{|c|}{$\begin{array}{l}1996 \\
\text { Cattle + horses }(0.4)\end{array}$}} & \multicolumn{4}{|c|}{2001} \\
\hline Large herbivores (nr. ha ${ }^{-1} \mathrm{y}^{-1}$ ) & \multicolumn{4}{|l|}{ Cattle (0.4) } & & & & & & & & & Cattle & & & \\
\hline Number of rabbit burrows ha ${ }^{-1}$ & \multirow{2}{*}{\multicolumn{4}{|c|}{$\begin{array}{l}0 \\
\text { Clay }\end{array}$}} & \multirow{2}{*}{\multicolumn{4}{|c|}{$\begin{array}{l}0 \\
\text { Clay }\end{array}$}} & \multirow{2}{*}{\multicolumn{4}{|c|}{$\begin{array}{l}0.7 \\
\text { Sandy loam }\end{array}$}} & \multirow{2}{*}{\multicolumn{4}{|c|}{$\begin{array}{l}2.3 \\
\text { Clay }\end{array}$}} \\
\hline Soil type & & & & & & & & & & & & & & & & \\
\hline Vegetation and soil type features & Gr & $\mathrm{Ju}$ & $\mathrm{Ca}$ & $\mathrm{Br}$ & $\mathrm{Gr}$ & $\mathrm{Ju}$ & $\mathrm{Br}$ & $\mathrm{O}$ & Gr & $\mathrm{Ru}$ & $\mathrm{Br}$ & $\mathrm{O}$ & Gr & $\mathrm{Ru}$ & $\mathrm{Br}$ & $\mathrm{O}$ \\
\hline$\%$ Cover per site & 56.1 & 27.8 & 11.9 & 4.2 & 53.6 & 21.6 & 20.7 & 4.1 & 36.4 & 35.3 & 4.1 & 24.2 & 63.3 & 28.4 & 5.1 & 3.2 \\
\hline Distribution & Pat/con. & Pat. & Pat. & Pat. & Pat/con. & Pat. & Pat. & Pat. & Pat. & Pat. & Pat. & Pat. & Cont. & Cont. & Pat. & Pat. \\
\hline Nat. regen. (saplings ha ${ }^{-1}$ ) & 18.1 & 54.3 & 34.9 & 49.2 & 3.8 & 29.4 & 22.7 & - & 17.5 & 42.1 & 32.0 & - & 0.3 & 3.1 & 8.9 & - \\
\hline Number of plots & 5 & 5 & 5 & 5 & 4 & 4 & 4 & - & 4 & 4 & 4 & - & 4 & 4 & 4 & - \\
\hline Soil moisture (Ellenberg) & 6.2 & 6.98 & 8.78 & 6.40 & 6.23 & 6.95 & 6.45 & - & 6.23 & 5.13 & 6.03 & - & 6.38 & 5.05 & 6.43 & - \\
\hline $\mathrm{pH}\left(\mathrm{H}_{2} \mathrm{O}\right)$ & 5.6 & 5.5 & 7.0 & 5.8 & 5.9 & 5.6 & 5.5 & - & 6.6 & 6.5 & 5.7 & - & 5.8 & 6.1 & 6.0 & - \\
\hline $\mathrm{K}(\mathrm{cmolc} / \mathrm{kg})$ & 0.18 & 0.18 & 0.21 & 0.22 & 0.19 & 0.16 & 0.26 & - & 0.49 & 0.38 & 0.37 & - & 0.40 & 0.34 & 0.16 & - \\
\hline Pextr. (mg/kg) & 19.25 & 16.80 & 26.96 & 22.03 & 17.14 & 16.28 & 8.30 & - & 35.64 & 31.40 & 28.77 & - & 14.99 & 29.43 & 17.78 & - \\
\hline Ptot (mg/kg) & 682.9 & 633.2 & 1463.1 & 860.8 & 684.1 & 737.1 & 557.6 & - & 729.4 & 406.8 & 643.5 & - & 426.2 & 451.6 & 451.3 & - \\
\hline L.O.I. $-550{ }^{\circ} \mathrm{C}(\%)$ & 10.12 & 11.11 & 13.56 & 10.74 & 10.81 & 9.66 & 8.77 & - & 8.38 & 3.44 & 5.93 & - & 4.00 & 3.48 & 5.01 & - \\
\hline L.O.I. $-900{ }^{\circ} \mathrm{C}(\%)$ & 1.09 & 1.48 & 1.12 & 1.48 & 1.43 & 1.44 & 1.21 & - & 0.96 & 0.60 & 0.74 & - & 0.88 & 0.93 & 0.90 & - \\
\hline $\mathrm{NO}_{3}^{-}(\mathrm{mgN} / 100 \mathrm{~g})$ & 0.72 & 1.67 & 1.20 & 1.07 & 0.92 & 0.95 & 0.77 & - & 0.86 & 0.68 & 0.42 & - & 0.49 & 0.47 & 0.29 & - \\
\hline $\mathrm{NH}_{4}^{+}(\mathrm{mgN} / 100 \mathrm{~g})$ & 1.10 & 0.96 & 0.89 & 0.67 & 0.46 & 0.56 & 2.50 & - & 4.11 & 0.54 & 0.82 & - & 0.80 & 0.65 & 0.84 & - \\
\hline
\end{tabular}

Seasonal grazing = May-October; $\mathrm{Gr}=$ grassland, Ju = Juncus, $\mathrm{Ca}=$ Carex, $\mathrm{Ru}=$ ruderal pioneer vegetation, $\mathrm{Br}=$ bramble, $\mathrm{O}=$ other types; nat. regen. = natural regeneration with woody species; pat. = patchily and not connected, pat/con. = patchily and connected, cont. = contiguous; Ellenberg = Ellenberg indicator values L.O.I. $=$ loss on ignition . 
at all study sites and partly of arable farming (drier slopes). Grazing management started immediately after the cessation of agricultural use. In all sites, this was less than 10 years ago (Table 1). Since cessation of agricultural use, vegetation mosaics with patches of short grassland, tall herbs, tall sedges (Carex sp.), soft rush tussocks (Juncus effusus) and bramble thickets (4-600 $\mathrm{m}^{2}$ ) developed. On the drier slopes, the mosaics consisted of patches with ruderal pioneer vegetations (on former arable land), short grazed grassland and shrub thickets.

At all sites, sparse natural regeneration of woody species took place (sapling density is given in Table 1 (summarised personal data)). In the grassland, saplings of F. excelsior, Q. robur and Alnus glutinosa are most frequent; on former arable land, sapling communities mainly consisted of Salix caprea, Betula pendula, F. excelsior and Q. robur. Scrub vegetation mainly consisted of bramble thickets (Rubus sp.) and small individual shrubs of spiny species (Prunus spinosa and Crataegus monogyna).

Rabbits (Oryctolagus cuniculus) were present in sites on drier slopes and were nearly absent in floodplains. Occurrence of rabbits was estimated by counting burrows (autumn, 2006). Burrows were only present in woodland and scrub vegetation. No roe deer were present in the sites.

\subsection{Experimental design}

We set up an experiment with seedlings of $Q$. robur and $F$. excelsior to study the interaction between vegetation type and grazing on the mortality and growth of seedlings. We established 56 plots, each divided in two adjacent subplots of $4 \mathrm{~m}^{2}$. One subplot was grazed (from the beginning of May 2004 onwards), the other was protected from large herbivore grazing by a barbed wire exclosure (control subplots). Plots were established in five different vegetation types: short grassland (short, dense lawns), Juncus vegetation (high tussocks), Carex vegetation (high, no tussocks), ruderal pioneer vegetation (short, thin vegetation on former arable land)

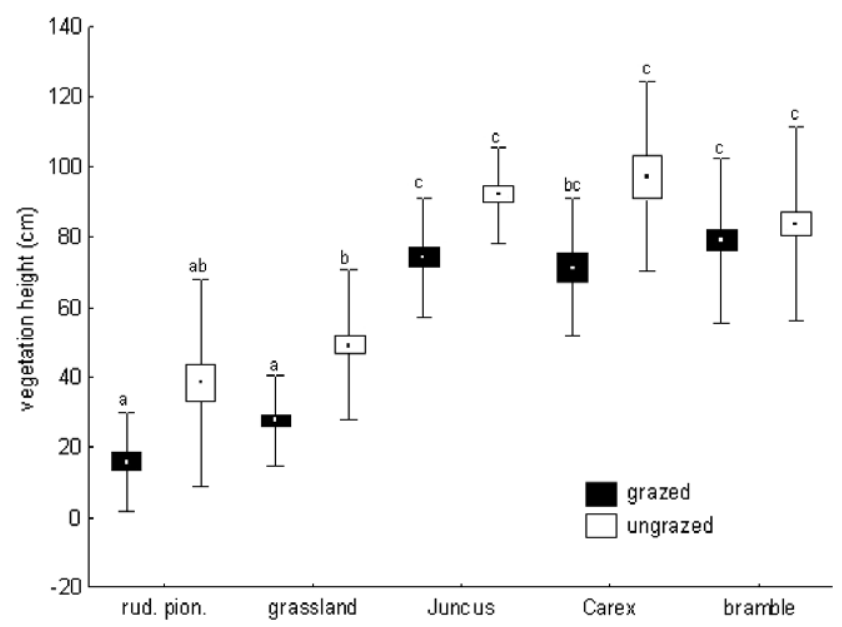

Fig. 1 - Average vegetation height $(\mathrm{cm})$ of different vegetation types (divided in a grazed and ungrazed subset); point $=$ mean, box $=$ st. err., whisker $=$ st. dev. Different letters indicate significantly different vegetation heights (Kruskal-Wallis Anova $\mathrm{H}(9, \mathrm{~N}=448)=271.1 ; \mathrm{P}<0.001$; multiple comparisons: $P<0.05$ ). and bramble (high thickets) (Fig. 1). Identification and location of the vegetation types in the field was mainly based on cover percentages of dominant species and former land use (in case of arable land). Juncus plots were dominated by J. effusus $(>80 \%)$, Carex vegetations were dominated by tall Carex species (> 80\%, dominated by C. acuta). Bramble vegetations consisted of various microspecies of the Rubus fruticosus group (>95\%). In grassland plots Poa trivialis or Holcus lanatus were the dominant species. Ruderal pioneer vegetations were less homogeneous, with Matricaria recutita, Poa annua, Conyza canadensis, Elymus repens, Sonchus oleraceus and Cirsium arvense as most abundant species. In all study sites grassland formed the matrix, in which patches of the other types occurred, except for ruderal pioneer vegetations on former arable land, which were found in adjacent parcels. Plots were established in the centre of vegetation patches $\left(>100 \mathrm{~m}^{2}\right)$. The number of plots, cover percentages, and distribution of the vegetation types in each site are given in Table 1.

In each subplot we planted 18 seedlings (nine Q. robur and nine F. excelsior). We used 2016 six month old seedlings, purchased from a commercial nursery. Seedlings had single stems with buds, but no leaves when planted (end of April 2004). Seedling length without roots varied from 20 to $40 \mathrm{~cm}$. In each subplot, nine F. excelsior and nine Q. robur seedlings were planted in a grid, allowing each individual seedling to be located and measured repeatedly.

We measured seedling height (top apical shoot) monthly during the first year (May 2004-April 2005). We recorded mortality (seedling disappeared or destroyed with dried out stem, apical shoot and buds) and damage, caused by large herbivore grazing, trampling, rabbit grazing and visual damage to leaves by insects, fungi and drought. Grazing damage by rabbits was easily distinguished from large herbivore grazing because rabbits cut seedling stems with a typical smooth, sloping sectional plane. Additional measurements of seedling height were done at the end of the second and third growing season in September 2005 and September 2006. In April 2006, poles and barbed wire of the exclosure subplots were removed to simulate a two year's initial time gap before grazing.

In September 2004, i.e. after the first growing season, we measured vegetation height at four fixed points in each subplot. Vegetation height was defined as the maximum height of the foliage at the point touched by a vertically held marked rod. It ranged from $15.8( \pm 14.3) \mathrm{cm}$ in grazed ruderal pioneer vegetations to $97.2( \pm 27.2) \mathrm{cm}$ in Carex vegetations (Fig. 1). Photosynthetic photon flux density ( $\mu$ mols photons $\mathrm{s}^{-1} \mathrm{~m}^{-2}$ ) was measured on cloudless days in September 2004 at $40 \mathrm{~cm}$ (eight fixed points) and $150 \mathrm{~cm}$ (1 point without interfering vegetation) above ground level, using a photometer (Skye Instruments LTD, SKP 200). Light penetration in the vegetation was determined as the ratio between measurements at 40 and $150 \mathrm{~cm}$. It was negatively correlated with vegetation height (Spearman rank order correlation: $R=-0.54$; $P<0.001)$. Light penetration was significantly higher in ruderal pioneer vegetations, grasslands and grazed Juncus vegetation than in bramble and Carex vegetation (Kruskal-Wallis $\mathrm{H}(9, \mathrm{~N}=896)=305.2 ; \mathrm{P}<0.001)$.

To characterise each study site, one soil sample per vegetation type was taken in June 2004. This sample consisted of five bulked subsamples taken up to a depth of $10 \mathrm{~cm}$. 
Inorganic nitrogen was determined as $\mathrm{KCl}$-extractable nitrate $\left(\mathrm{NO}_{3}^{-}\right)$and ammonium $\left(\mathrm{NH}_{4}^{+}\right)$. Resin-extractable phosphorus $\left(P_{\text {ext }}\right)$ was analysed using the method of (Lajtha et al., 1999). Total phosphorus $\left(P_{\text {tot }}\right)$ was determined after microwave digestion of soils using ICP spectroscopy (Kuo, 1996). Cation exchange capacity and concentrations of exchangeable cations (potassium) was determined according to the Silver-thiourea method (Pleysier and Juo, 1980). Organic matter and carbonate contents were determined as weight loss after ignition (L.O.I.) at 550 and $900{ }^{\circ} \mathrm{C}$ respectively. DCA-analysis of these soil characteristics revealed no clear distinction between vegetation types. Soil differences rather distinguished floodplains and drier slopes, the former having higher extractable $\mathrm{NO}_{3}^{-}$-concentrations and higher organic matter content; the latter having relatively low $\mathrm{P}_{\text {tot-concentrations }}$ and higher extractable $\mathrm{K}$-concentrations (Table 1 ).

Soil moisture was estimated using weighted averages of Ellenberg's indicator values (Ellenberg et al., 1992). Indicator values ranged from 5.1 to 8.8 (Table 1). With the exception of Carex plots (wet), all plots were in an ecological range from average moist to moist soils.

\subsection{Data analysis}

We used general linear mixed models to analyse growth (SAS 9.1, proc mixed). Generalised linear mixed models (SAS 9.1, proc glimmix) were used to analyse mortality. A random effects structure was build for both model types. A logit transformation was performed for binomial distributed data (mortality). In order to get insight in the complex data structure and the importance of the random factor "site", we initially analysed the first year's data of exclosure plots separately. Analyses of growth were performed for Q. robur and F. excelsior separately, because important differences in growth rate and regeneration capacity are intrinsic to the species (F. excelsior growing and regenerating faster). Negative growth means that an individual seedling is smaller than in the beginning of the experiment (time of planting). In the analyses, we entered 'vegetation type', 'treatment' (grazed vs. ungrazed), and 'species' ( $Q$. robur vs. F. excelsior) as fixed factors. Time (1, 2 or 2.5 years) was included as a repeated measures factor. 'Site', 'plot' and 'individual seedling' were modelled as random factors, with individual seedling nested in plot and plot nested in vegetation type. The number of degrees of freedom was estimated using the method of Kenward and Roger (1997). Initial models included all variables and all interactions. Non-significant factors and interactions were gradually eliminated, using a backward procedure. AIC values for goodness of model fit (Akaike, 1987) were used to control, whether the model was improved or not after elimination. To control for independence of the two species, the experimental set up provided the same conditions in all plots. So, if there's any interaction, it will be the same everywhere. We could not test for independence statistically. Given the experimental set up and duration of the experiment, we didn't expect a significant influence. The influence of time gap treatment (2 years ungrazed, 1 season grazed) on mortality and growth was analysed in the same way, comparing it to the continuously grazed plots. Tukey-tests were performed to make multiple comparisons in all mixed model analyses.

\section{Results}

\subsection{Random factors 'site' and 'plot'}

We used a comparison of the control plot (ungrazed) data to assess the role of site and plot. We did not find significant differences in mortality and growth in different vegetation types. In the mortality analysis, $Q$. robur had a significant higher mortality than $F$. excelsior ( $F 1,102=5.45 ; p=0.02$ ). Random factors site and plot did not contribute to the model in a significant way (covariance parameter estimates for site: $s^{2}=0.23( \pm 0.19$ SE) and for plot: $s^{2}=0.35( \pm 0.28 \mathrm{SE})$ ). Variation explained by random factors "site" and "plot" was constantly low (between $3.4 \%$ and $8.2 \%$ ), compared to the residual variance.

\subsection{Mortality}

Depending on treatment (grazed vs. ungrazed), time (1-2.5 years), species and vegetation type, mortality varied between $0 \%$ and $75 \%$ (Fig. 2). The average mortality after 1 year was about $17.5 \%$ in ungrazed plots and $35.8 \%$ in grazed plots. Treatment and time were the most important factors, having significant interactions with vegetation type (Table 2). In ungrazed plots, mortality rate was highest in bramble plots, but for $Q$. robur not significantly higher than in other vegetation types; in grazed plots the highest mortality rate was found in grassland plots. In general, for both $Q$. robur and $F$. excelsior, mortality was higher in grazed plots. No significant differences in mortality, between grazed and ungrazed plots, were found in bramble (both species), Juncus and Carex plots (for F. excelsior only) (Fig. 2).

Although mortality was higher in Q. robur than in F. excelsior (Fig. 2), differences in mortality frequency were low (on average less than 10\%). This was the case for both grazed and ungrazed plots.

Mortality generally increased with increasing grazing time. However, additional mortality in years two and three was always low compared to the first year's mortality (Fig. 2). In grazed plots, differences among vegetation types decreased with increasing grazing time, but not for grassland plots in which the mortality rate was significantly higher than in all other types.

Rabbit (O. cuniculus) grazing caused death of $6.3 \%$ of all seedlings in the experiment (= $1 / 5$ of all died individuals). In the floodplains, $1.8 \%$ of all seedlings died due to rabbit grazing; on drier slopes, this was $12.9 \%$. Mortality due to rabbits mainly occurred in bramble plots (87.5\% of all cases). There were no differences due to rabbit grazing between $Q$. robur and F. excelsior, nor between grazed and ungrazed plots. Although rabbit densities and rabbit grazing damage differed considerably among sites, there were no significant differences in total mortality among sites after 2.5 years.

Drought caused death of $0.9 \%$ of all seedlings $(=2.6 \%$ of all died individuals) and was only observed in Steenbergbos and Boelaremeersen.

\subsection{Growth}

Average growth ranged from -17 to $+52 \mathrm{~cm}$ for $F$. excelsior and from -36 to $+52 \mathrm{~cm}$ for Q. robur (Fig. 3). For both Q. robur and 

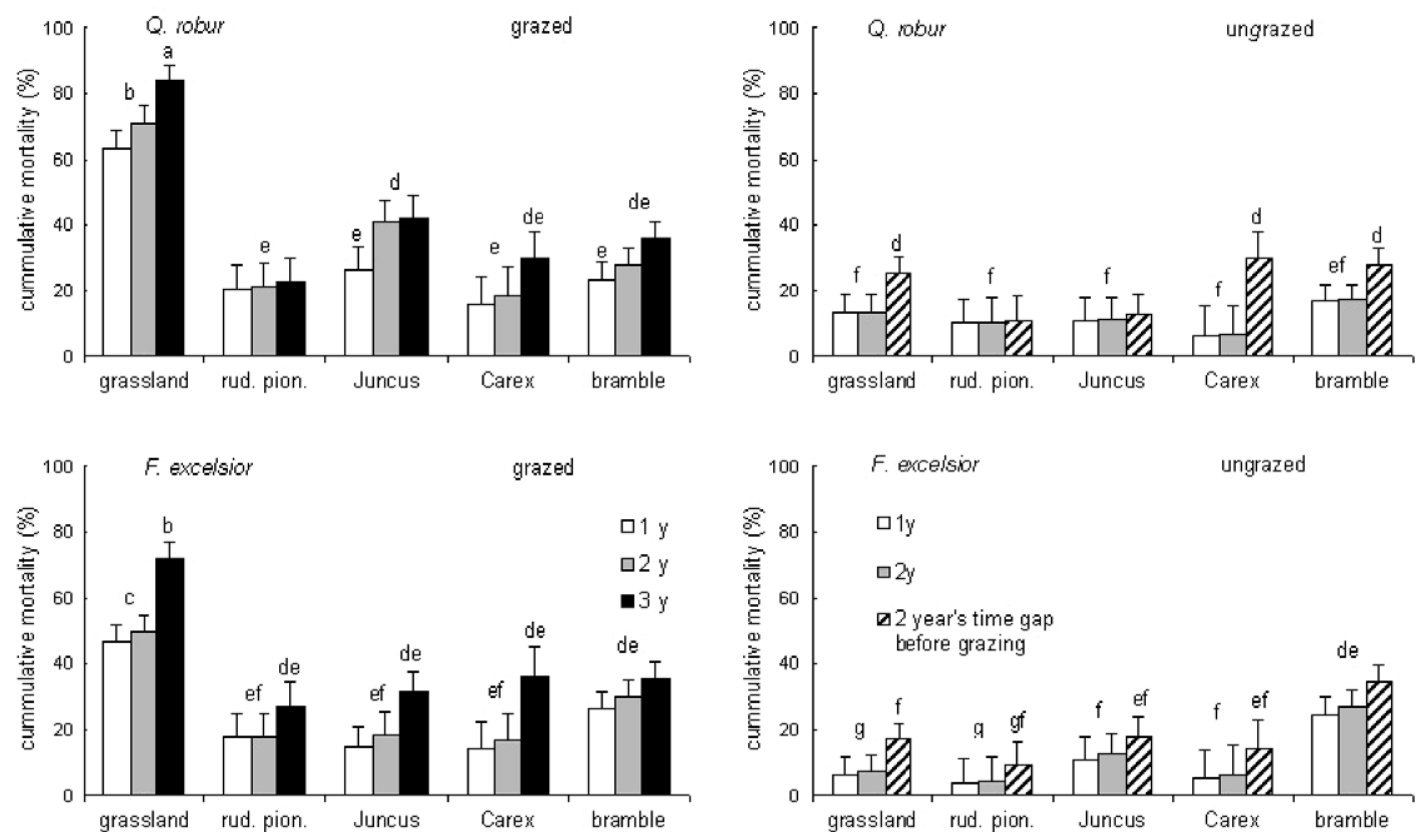

Fig. 2 - Cumulative mortality percentages (mean + st. err.) of Quercus robur and Fraxinus excelsior seedlings in different vegetation types, after 1st, 2nd and 3rd growing season and under different treatments. In the ungrazed plots, exclosures were removed after two years (time gap treatment). Grazing there started in the 3rd growing season (diagonal bars). Different letters indicate significantly different values (multiple comparisons with Tukey-tests, $P<0.05$ ).

F. excelsior, treatment, time, vegetation type (not for F. excelsior) and the two-way interactions between these factors were significant (Table 2). Negative growth in this context means a lower seedling height compared to the height at the time of planting. Comparing both treatment types, a significant lower average growth was found in grazed plots, except for Q. robur in bramble and one year grazed Carex plots and for F. excelsior in bramble, Carex and one year grazed Juncus plots (Tukey-test: all $P>0.05$, Fig. 3).

The effects of vegetation type were mainly significant in grazed plots. The highest average growth was found in bramble thickets for both species. For Q. robur, growth was

Table 2 - Results of the GLM-analysis with mortality (\%) and growth as dependent and vegetation type (veg), treatment (treatm), time and species as independent variables

\begin{tabular}{|c|c|c|c|c|c|}
\hline & Factor & Nom. d.f. & Den. d.f. & $F$ value & $\operatorname{Pr}>F$ \\
\hline \multirow[t]{9}{*}{ Mortality } & Veg & 4 & 19 & 1.29 & 0.308 \\
\hline & Treatm & 1 & 516 & 48.24 & 0.003 \\
\hline & Time & 2 & 516 & 66.79 & $<0.001$ \\
\hline & Species & 1 & 516 & 4.17 & 0.042 \\
\hline & Veg"treatm & 4 & 516 & 16.07 & $<0.001$ \\
\hline & Veg"species & 4 & 516 & 4.13 & 0.003 \\
\hline & Time*veg & 4 & 516 & 8.86 & $<0.001$ \\
\hline & Time*treatm & 2 & 516 & 4.97 & 0.026 \\
\hline & Treatm“species & 4 & 516 & 5.06 & 0.025 \\
\hline \multicolumn{6}{|l|}{ Growth } \\
\hline \multirow[t]{6}{*}{ Q. robur } & Veg & 4 & 97.5 & 5.59 & $<0.001$ \\
\hline & Treatm & 1 & 2405 & 4.35 & 0.037 \\
\hline & Time & 2 & 2405 & 71.18 & $<0.001$ \\
\hline & Veg"treatm & 4 & 2405 & 24.46 & $<0.001$ \\
\hline & Time*treatm & 2 & 2405 & 114.35 & $<0.001$ \\
\hline & Time*veg & 8 & 2405 & 6.93 & $<0.001$ \\
\hline \multirow[t]{6}{*}{ F. excelsior } & Veg & 4 & 68.8 & 1.61 & 0.182 \\
\hline & Treatm & 1 & 2405 & 7.94 & 0.005 \\
\hline & Time & 2 & 2405 & 103.95 & $<0.001$ \\
\hline & Veg*treatm & 4 & 2405 & 41.23 & $<0.001$ \\
\hline & Time"treatm & 2 & 2405 & 111.30 & $<0.001$ \\
\hline & Time*veg & 8 & 2405 & 3.89 & 0.004 \\
\hline
\end{tabular}

Time: 1-2.5 years (2 years for ungrazed plots). 

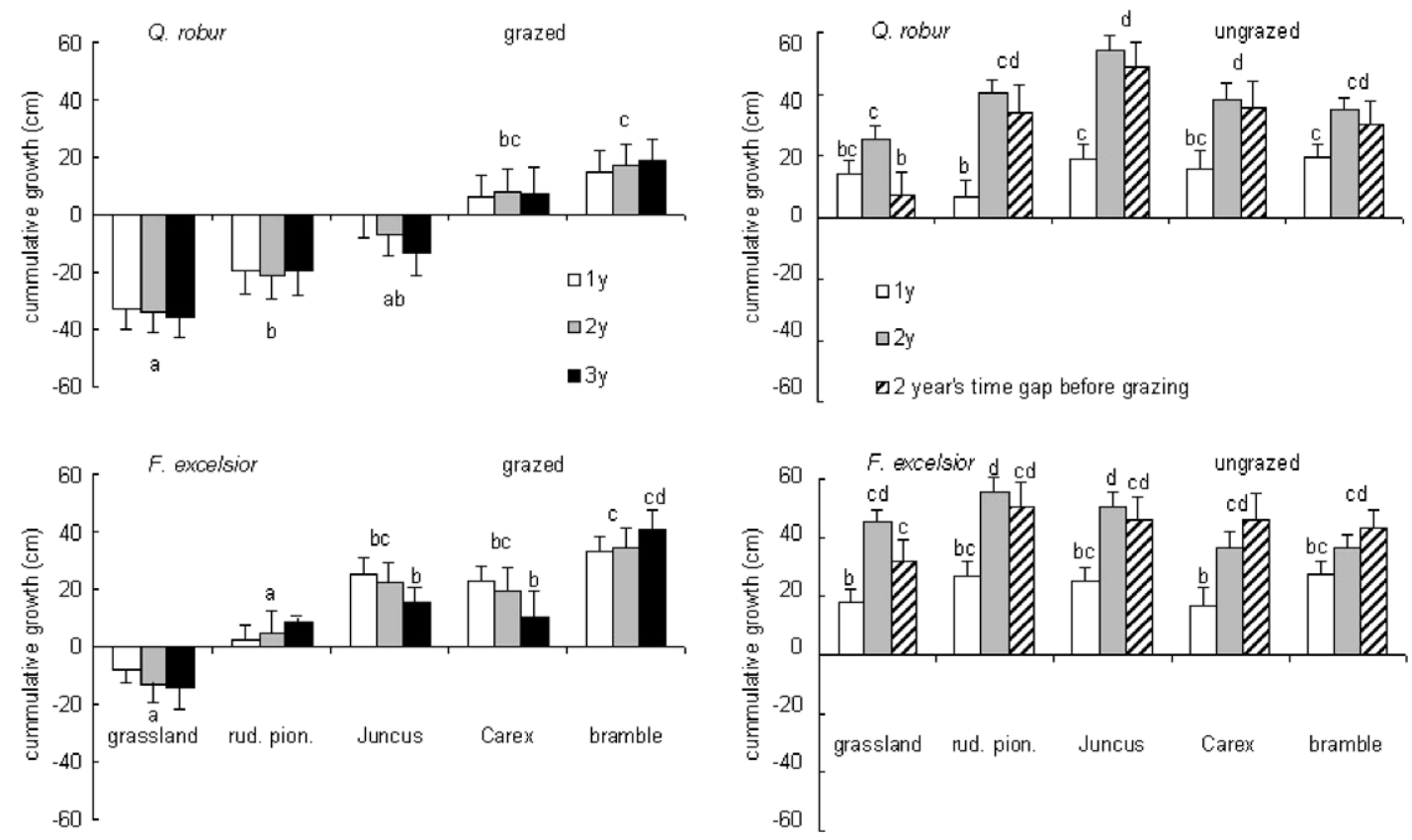

Fig. 3 - Cumulative growth (mean + st. err.) of Quercus robur and Fraxinus excelsior seedlings in different vegetation types, after 1st, 2nd and 3rd growing season and under different treatments. In the ungrazed plots, exclosures were removed after two years (time gap treatment). Grazing there started in the 3rd growing season (diagonal bars). Mean negative growth occurs when the mean height of seedlings is lower than the mean height at the starting point of the experiment. Different letters indicate significantly different values (multiple comparisons with Tukey-tests, $P<0.05$ ).

on average negative in grassland, ruderal pioneer vegetations and Juncus vegetation (Fig. 3). For F. excelsior, average growth was negative in grassland and low in ruderal pioneer vegetation. Carex and Juncus vegetations took an intermediate position, with a significantly higher seedling growth compared to grassland and ruderal pioneer vegetation, but no significant differences with growth in bramble (except for 2.5 years grazed Carex and Juncus plots, Fig. 3).

In ungrazed plots, growth increased with increasing time (data for two years only) in all cases (Fig. 3). In grazed plots, differences in growth among different grazing times were small. Even in vegetation types with a positive average growth in subsequent years, no significant differences were found among different grazing times (Tukey-test: all $P>0.05$ ).

The number of individuals able to grow, varied in different vegetation types. Percentages were low in grassland for both Q. robur and F. excelsior and in Juncus vegetation for $Q$. robur $( \pm 9-24 \%)$ compared to other vegetation types $( \pm 40-70 \%)$.

\subsection{Time gaps}

A two year's time gap before subsequent grazing (during 6 months) reduced mortality of seedlings in a significant way, compared to the 2.5 years continuous-grazing treatment, in grassland and ruderal pioneer vegetation for both tree species and in Juncus plots (for Q. robur only). Among other vegetation types, there were no significant differences, but in general, mortality was lower in the plots with a grazing time gap.

Time gaps resulted in a significant higher growth of $F$. excelsior $(32.4-50.9 \mathrm{~cm})$ and Q. robur $(7.6-49.2 \mathrm{~cm})$ compared to the 2.5 years grazing treatment (Fig. 3). However, no significant differences were found in bramble thickets (Tukey-test: all $P>0.05)$. Among different vegetation types with the time gap treatment, differences in growth were small. A positive average growth after opening the exclosure plots was only observed in bramble and Carex plots (F. excelsior, on average 4.9 and $8.2 \mathrm{~cm}$ respectively). In grassland, average growth decreased significantly for $Q$. robur; in the other vegetation types growth came to a standstill for both tree species.

\section{Discussion}

Olff et al. (1999) and Vera (2000) described the mechanism of associational resistance and woody species colonization for diverse ecosystems, but stressed the need for an experimental basis. This study provides experimental evidence for this mechanism on nutrient rich soils in a broad geomorphological range. The mechanism was effective in both seasonal and year-round grazed ecosystems. Foraging on tree seedlings was largely restricted to spring and summer, when seedlings had nutritious buds and green leaves and, as a consequence, no differences were found between those two grazing management strategies (Van Uytvanck, unpublished data).

\subsection{Bramble and tall herb patches as safe sites}

Large herbivore grazing is an important factor causing death of seedlings. In grazed grasslands, survival of seedlings was highly constrained by grazing and browsing, whereas competition for light, rabbit grazing and, to a lesser extent, drought caused death in ungrazed circumstances. In natural and semi-natural circumstances, these stress factors were found 
to be equally or even more important than grazing (Frost and Rydin, 1997; Pépin et al., 2006). In woodpastures in the Swiss Jura, desiccation of seedlings was the most common cause of seedling death (Vandenberghe et al., 2006). In the same area, Smit et al. (2006) found that grazing was the major cause of death, except for saplings planted near unpalatable Gentiana species. In the absence of grazing, we found the highest mortality of seedlings in the relatively dark bramble thickets. Kelly (2002) found that, in the absence of large herbivores, light was the limiting factor for tree regeneration (Q. petraea) in grazed woodlands. Our results suggest a shift from light deficiency to large herbivore grazing damage as the limiting factor for survival of seedlings in grazed mosaic vegetations.

Highest mortality $( \pm 90 \%)$ appeared during the first year, which corresponds with results of De Steven (1991a). In subsequent years, surviving seedlings became stronger and less vulnerable to grazing damage. As a consequence, the structural features and the ability of vegetation types to offer protection immediately after the germination of tree seedlings, is, to a large extent, determining the survival of these seedlings.

Large grazers prefer short vegetation types with sufficient nutrient rich leaves (WallisDeVries et al., 1999). Associational palatability caused a very low survival rate of tree seedlings in our grassland plots. Our results showed that in the unpalatable and taller Juncus and Carex vegetations, seedlings were able to become larger and, as a consequence, had more chance to survive. This corresponds with the findings that tall forbs and dense vegetations can facilitate the establishment of seedlings (De Steven, 1991a; Kollmann and Schill, 1996; Negi et al., 1996; Callaway et al., 2000). Unpalatable species can do the same (Callaway et al., 2005; Smit et al., 2005; Smit et al., 2006). Pollock et al. (2005) found that browsing intensity on saplings was negatively related to good quality biomass available for herbivores and adjacent vegetation height. In this study, Carex vegetations, which form high and dense vegetations, were only used as food supply in dry periods (Van Uytvanck, personal observations). Pelster et al. (2004) found reduced willow consumption in tall sedge vegetations higher than $20 \mathrm{~cm}$. Juncus effusus is an unpalatable species with low nutritional value (Hopkins and Peel, 1985), which is only eaten in wintertime when food supply is low. On former arable land, a sparse vegetation with prickly or spiny and unpalatable forbs was present. It did not attract herbivores, but seedlings were easily perceptible. Prickly species (Cirsium arvense and Urtica dioica) began to dominate two or three years after abandonment. Associational resistance possibly explains why an increasing number of $F$. excelsior seedlings was able to grow in these vegetations types in year two and three. However, the studied tall herb and ruderal communities only offer growth possibilities to a certain extent. Kuiters and Slim (2003) also found rush tussocks and heather dwarf shrub patches, facilitating $Q$. robur and Frangula alnus regeneration in abandoned and grazed arable land on poor sandy soils. But even after 30 years, few saplings had grown beyond the browse-line.

In the presence of large herbivores, spiny shrub species are thought to be the most logical safe sites for trees (Callaway, 1992; Callaway and Davis, 1998; Castro et al., 2004). Kuiters and Slim (2003) demonstrated the important role of bramble thickets for tree regeneration in abandoned fields. Bakker et al. (2004) found P. spinosa to be an effective safe site for $Q$. robur in woodpastures. Clonal expansion by root suckers can form dense patches of spiny shrub thickets, which grow out in a horizontal direction. A comparable mechanism operates with Rubus species, which grow out with above ground suckers, forming large and dense thickets. Our experiments confirm the effective protection that bramble thickets provide against large herbivores. Single thorny shrubs such as $C$. monogyna, may not provide sufficient shelter for seedlings and young trees because growth mainly follows a vertical direction. Moreover, thorns are only formed after one year. Although all woody species are vulnerable to grazing at the early establishment phase, the fast growth of Rubus sp. on former agricultural land enables the formation of protective thickets much earlier, compared to slower growing Crataegus species and P. spinosa. This is important because shrub thickets have to be large enough to function as an effective barrier for grazers (Gómez et al., 2001).

On the other hand, dense or high vegetation types are a safe and attractive environment for small herbivores (e.g. small rodents like voles), which consume seedlings and seeds (Ostfeld and Canham, 1993; Weltzin et al., 1997; Hubbard and McPherson, 1999). In our study, rabbits (O. cuniculus) were the most important small herbivores. In riverine floodplains Bakker et al. (2004) found that main differences in tree regeneration were due to differences in rabbit densities. Q. robur could not be protected by $P$. spinosa thickets against rabbits. High densities of rabbits are able to completely prevent regeneration of woody species in abandoned fields (Oosterveld, 1983). Small herbivores like red-bellied pademelons (Thylogale billardierii) even select seedlings to consume in an unpalatable neighbourhood (Miller et al., 2007). At our study sites, rabbits were present in low densities, but burrows were concentrated in bramble thickets. Rabbits also preferred foraging on tree seedlings in the protective thickets above foraging in open vegetation types, where grazing damage was nearly absent. In bramble thickets, rabbit grazing was the major factor causing mortality of seedlings. However, it is still possible that in the end, seedling mortality in bramble thickets mainly depends on light conditions since in our study, after 2.5 years, there were no significant differences in mortality among bramble plots with high or low rabbit densities. Probably rabbit grazing only accelerates seedling mortality in bramble thickets, while mortality due to unfavourable light conditions, is a slower process.

Whether enhanced establishment in the protective vegetation types will finally lead to a desired woodpasture vegetation structure is not yet clear. Our experiment lasted three growing seasons, but the natural regeneration pattern of woody species in Bos t' Ename, Rietbeemd and Boelaremeersen (grazed since 1996, 1997 and 2001 respectively) generally confirms the role of the studied vegetation types: grown out trees in bramble patches, short grazed trees in Juncus and Carex patches. However, very low absolute numbers $\left(<5 \mathrm{ha}^{-1}\right)$ of grown out trees were present (Table 1).

\subsection{Time gaps}

To maintain woodpastures, a balance between consumption and regeneration of tree species is needed. In woodpastures, 
regeneration capacity is an important feature for woody species. F. excelsior regenerated faster and better (possibly after successive grazing events in one season) than $Q$. robur. As a consequence, F. excelsior is able to persist in vegetation types where grazing pressure is moderate (tall herb vegetation), whereas $Q$. robur clearly needs more protection. Only reduced grazing pressure or time gaps in grazing management may finally lead to successful establishment of palatable species outside shrub thickets (Mountford and Peterken, 2003). Kuiters and Slim (2002) argue that browse-sensitive woody species such as Quercus species will successfully regenerate, only if temporal and spatial variation in browsing pressure can occur. If not, woodland regeneration on abandoned land may take several decades (Smit and Olff, 1998; Harmer et al., 2001). Vera (2000) opposes this idea, assigning Quercus sp. to the browse-tolerant trees.

Because of the proven importance of the seedling's first year, a time gap before grazing had a large positive impact on seedling survival. However, a period of two years seems to be too short to enable a sufficient outgrowth. In Australian rangelands, sheep and cattle entered tall vegetations after the removal of exclosures. Damage to juvenile trees was due to sheep grazing, cattle trampling and breaking stems (Clarke, 2002). Extending time gaps before grazing may be an option, but in species rich grasslands it carries the risk of biodiversity loss due to the strong expansion of tall herbs (Bakker et al., 2002).

\subsection{Conclusions and applications for conservation management}

Restoration of woodpastures, departing from agricultural land, starts with the process of woody species regeneration. Apart from dispersion (Kollmann and Pirl, 1995) and germination (De Steven, 1991b), establishment of woody species faces a double bottleneck: survival and outgrowth. The combination of safe sites and specific management measures can overcome these initial bottlenecks.

Moderate grazing induces the development of diverse vegetation pattern in a few years' time (Van Den Bos and Bakker, 1990). In this pattern, bramble thickets play a key-role: they function as safe sites in which palatable tree species can survive and grow out. Tall herb and ruderal vegetations may be temporal safe sites for woody seedlings: survival is enhanced, but outgrowth will only be possible in periods with low or temporally absent grazing pressure. In homogeneous grassland, woodland regeneration is almost impossible, even with very low herbivore densities.

Initial time gaps before grazing may enhance regeneration success and accelerate the restoration process in woodpastures. However, conservation managers should find a good balance between the conservation of present grassland biodiversity and spontaneous regeneration of woody species.

\section{Acknowledgements}

Sophie Vanroose, Arjen Breevaert and Pieter Blondé for assistance during fieldwork. Guido Tack, Joris De Wolf, Godfried Merlevede and Johnny Cornelis granted us permission to set up the experiment in the study sites. Frederik Hendrickx, Dirk Bauwens and Paul Quataert provided statistical help. We thank two anonymous reviewers for their helpful comments.

\section{R E F E R E N C E S}

Akaike, H., 1987. Factor analysis and AIC. Psychometrika 52, 317-332.

Bakker, E.S., Olff, H., Vandenberghe, C., De Maeyer, K., Smit, R., Gleichman, J.M., Vera, F.W.M., 2004. Ecological anachronisms in the recruitment of temperate light-demanding tree species in wooded pastures. Journal of Applied Ecology 41, 571-582.

Bakker, J.P., Marrs, R.H., Pakeman, R.J., 2002. Long-term vegetation dynamics: Successional patterns and processes. Introduction. Applied Vegetation Science 5, 2-6.

Bakker, J.P., Londo, G., 1998. Grazing for conservation management in historical perspective. In: Wallis DeVries, M., Bakker, J.P., van Wieren, S.E. (Eds.), Grazing and Conservation Management. Kluwer Academic Publishers., Dordrecht, pp. 23-54.

Bokdam, J., Gleichman, J.M., 2000. Effects of grazing by freeranging cattle on vegetation dynamics in a continental north-west European heathland. Journal of Applied Ecology 37, 415-431.

Bossuyt, B., De Fre, B., Hoffmann, M., 2005. Abundance and flowering success patterns in a short-term grazed grassland: early evidence of facilitation. Journal of Ecology 93, 1104-1114.

Callaway, R.M., 1992. Effect of shrubs on recruitment of Quercus douglasii and Quercus lobata in California. Ecology 73, 2118-2128.

Callaway, R.M., Davis, F.W., 1998. Recruitment of Quercus agrifolia in central California: the importance of shrub-dominated patches. Journal of Vegetation Science 9, 647-656.

Callaway, R.M., Kikodze, D., Chiboshvili, M., Khetsuriani, L., 2005. Unpalatable plants protect neighbors from grazing and increase plant community diversity. Ecology 86, 1856-1862.

Callaway, R.M., Kikvidze, Z., Kikodze, D., 2000. Facilitation by unpalatable weeds may conserve plant diversity in overgrazed meadows in the Caucasus Mountains. Oikos 89, 275-282.

Castro, J., Zamora, R., Hódar, J.A., Gómez, J.M., Gómez-Aparicio, L., 2004. Benefits using shrubs as nurse plants for reforestation in Mediterranean mountains: a 4-year study. Restoration Ecology 12, 352-358.

Clarke, P.J., 2002. Experiments on tree and shrub establishment in temperate grassy woodlands: seedling survival. Austral Ecology 27, 606-615.

Davidson, D.W., 1993. The effects of herbivory and granivory on terrestrial plant succession. Oikos 68, 23-35.

De Steven, D., 1991a. Experiments on mechanisms of tree establishment in old-field succession: seedling survival and growth. Ecology 72, 1076-1088.

De Steven, D., 1991b. Experiments on mechanisms of trees establishment in old-field succession: seedling emergence. Ecology 72, 1066-1075.

Dennis, P., Young, M.R., Gordon, I.J., 1998. Distribution and abundance of small insects and arachnids in relation to structural heterogeneity of grazed, indigenous grasslands. Ecological Entomology 23, 253-264.

Ellenberg, H., Weber, H.E., Düll, R., Wirth, V., Werner, W., Paulißen, D., 1992. Zeigerwerte von Pflanzen in Mitteleuropa. Scripta Geobotanica 18, auflage 2.

Frost, I., Rydin, H., 1997. Effects of competition, grazing and cotyledon nutrient supply on growth of Quercus robur seedlings. Oikos 79, 53-58.

Gómez, J.M., Hodar, J.A., Zamora, R., Castro, J., Garcia, D., 2001. Ungulate damage on Scots pines in Mediterranean 
environments: effects of association with shrubs. Canadian Journal of Botany-Revue Canadienne de Botanique 79, 739746.

Harmer, R., Peterken, G., Kerr, G., Poulton, P., 2001. Vegetation changes during 100 years of development of two secondary woodlands on abandoned arable land. Biological Conservation 101, 291-304.

Hopkins, A., Peel, S., 1985. Incidence of weeds in permanent grassland. In: Brockman, J.S. (Ed.), Weeds, Pests and Diseases of Grassland and Herbage Legumes. British Crop Protection Council, Croydon, pp. 223-227.

Hubbard, J.A., McPherson, G.R., 1999. Do seed predation and dispersal limit downslope movement of a semi-desert grassland/oak woodland transition? Journal of Vegetation Science 10, 739-744

Humphrey, J., Gill, R., Claridge, J., 1998. Grazing as a Management Tool in European Forest Ecosystems. Forestry Commission, Edinburgh.

Kelly, D.L., 2002. The regeneration of Quercus petraea (sessile oak) in southwest Ireland: a 25-year experimental study. Forest Ecology and Management 166, 207-226.

Kenward, M.G., Roger, J.H., 1997. Small sample inference for fixed effects from restricted maximum likelihood. Biometrics 53, 977-983.

Kirby, K., Thomas, R., Key, R., McLean, I., Hodgetts, N., 1995. Pasture-woodland and its conservation in Britain. Biological Journal of the Linnean Society 56 (suppl), 135-153.

Kollmann, J., Pirl, M., 1995. Spatial pattern of seed rain of fleshy-fruited plants in a scrubland grassland transition. Acta Oecologica - International Journal of Ecology 16, 313-329.

Kollmann, J., Schill, H.P., 1996. Spatial patterns of dispersal, seed predation and germination during colonization of abandoned grassland by Quercus petraea and Corylus avellana. Vegetatio 125, 193-205.

Kuiters, A.T., Slim, P.A., 2002. Regeneration of mixed deciduous forest in a Dutch forest-heathland, following a reduction of ungulate densities. Biological Conservation 105, 65-74.

Kuiters, A.T., Slim, P.A., 2003. Tree colonisation of abandoned arable land after 27 years of horse-grazing: the role of bramble as a facilitator of oak wood regeneration. Forest Ecology and Management 181, 239-251.

Kuo, S., 1996. Phosphorus. In: Sparks, D.L. (Ed.), Methods of Soil Analysis. Soil Science Society of America, Wisconsin (USA), pp. 869-919.

Lajtha, K., Driscoll, C., Jarrell, W., Elliott, E.T., 1999. Soil phosphorus: characterization and total element analysis. In: Robertson et al. (Eds.), Standard Soil Methods for Long Term Ecological Research. Oxford University Press, New York, pp. 115-142.

Manning, A.D., Fischer, J., Lindenmayer, D.B., 2006. Scattered trees are keystone structures -implications for conservation. Biological Conservation 132, 311-321.

Miller, A.M., McArthur, C., Smethurst, P.J., 2007. Effects of withinpatch characteristics on the vulnerability of a plant to herbivory. Oikos 116, 41-52.

Mountford, E.P., Peterken, G.E., 2003. Long-term change and implications for the management of woodpastures: experience over 40 years from Denny Wood, New Forest. Forestry 76, 19-43.

Negi, A.S., Negi, G.C.S., Singh, S.P., 1996. Establishment and growth of Quercus floribunda seedlings after a mast year. Journal of Vegetation Science 7, 559-564.

Olff, H., Ritchie, M.E., 1998. Effects of herbivores on grassland plant diversity. Trends in Ecology and Evolution 13, 261-265.

Olff, H., Vera, F.W.M., Bokdam, J., Bakker, E.S., Gleichman, J.M., De Maeyer, K., Smit, R., 1999. Shifting mosaics in grazed woodlands driven by the alternation of plant facilitation and competition. Plant Biology 1, 127-137.
Oosterveld, P., 1983. Eight years of monitoring of rabbits and vegetation development on abandoned arable fields grazed by ponies. Acta Zoologica Fennica 174, 71-74.

Ostfeld, R.S., Canham, C.D., 1993. Effects of meadow vole population-density on tree seedling survival in old fields. Ecology 74, 1792-1801.

Pelster, A.J., Evans, S., Leininger, W.C., Trlica, M.J., Clary, W.P., 2004 Steer diets in a montane riparian community. Journal of Range Management 57, 546-552.

Pépin, D., Renaud, P.C., Boscardin, Y., Goulard, A., Mallet, C., Anglard, F., Ballon, P., 2006. Relative impact of browsing by red deer on mixed coniferous and broad-leaved seedlings - an enclosure-based experiment. Forest Ecology and Management 222, 302-313.

Peterken, G.F., Tubbs, C.R., 1965. Woodland regeneration in the New forest, Hampshire since 1650. Journal of Applied Ecology 2, 159-170.

Pleysier, J.L., Juo, A.S.R., 1980. A single-extraction method using silver-thiourea for measuring exchangeable cations and effective CEC in soils with variable charges. Soil Science 129, 205-211.

Pollock, M.L., Milner, J.M., Waterhouse, A., Holland, J.P., Legg, C.J., 2005. Impacts of livestock in regenerating upland birch woodlands in Scotland. Biological Conservation 123, $443-452$.

Pott, R., 1998. Effects of human interference on the landscape with special reference to the role of grazing livestock. In: Wallis DeVries, M., Bakker, J.P., van Wieren, S.E. (Eds.), Grazing and Conservation Management. Kluwer Academic Publishers., Dordrecht, pp. 107-134.

Pott, R., Hüppe, J., 1991. Die Hudelandschaften Nordwestdeutschlands. Westfälisches Museum für Naturkunde, Münster.

Quelch, P.R., 2001. An Illustrated Guide to Ancient Wood Pasture in Scotland. Forestry Commission, National Office for Scotland.

Rosen, E., Bakker, J.P., 2005. Effects of agri-environment schemes on scrub clearance, livestock grazing and plant diversity in a low-intensity farming system on Oland, Sweden. Basic and Applied Ecology 6, 195-204.

Rousset, O., Lepart, J., 2000. Positive and negative interactions at different life stages of a colonizing species (Quercus humilis). Journal of Ecology 88, 401-412.

Rousset, O., Lepart, J., 2003. Neighbourhood effects on the risk of an unpalatable plant being grazed. Plant Ecology 165, 197-206.

Rozas, V., 2004. A dendroecological reconstruction of age structure and past management in an old-growth pollarded parkland in northern Spain. Forest Ecology and Management 195, 205-219.

Smit, C., Beguin, D., Buttler, A., Muller-Scharer, H., 2005. Safe sites for tree regeneration in wooded pastures: a case of associational resistance? Journal of Vegetation Science 16, 209-214.

Smit, C., Den Ouden, J.A.N., Muller-Scharer, H., 2006. Unpalatable plants facilitate tree sapling survival in wooded pastures. Journal of Applied ecology 43, 305-312.

Smit, R., Olff, H., 1998. Woody species colonisation in relation to habitat productivity. Plant Ecology 139, 203-209.

Tubbs, C.R., 1986. The New Forest. Collins, London.

Van Den Bos, J., Bakker, J.P., 1990. The development of vegetation patterns by cattle grazing at low stocking density in the Netherlands. Biological Conservation 51, 263-272.

van Wieren, S.E., 1998. Effects of large herbivores upon the animal community. In: WallisDeVries, M.F. (Ed.), Grazing and Conservation Management. Kluwer Academic Publishers., Dordrecht, pp. 168-214. 
Vandenberghe, C., Frelechoux, F., Gadallah, F., Buttler, A., 2006. Competitive effects of herbaceous vegetation on tree seedling emergence, growth and survival: does gap size matter? Journal of Vegetation Science 17, 481-488.

Vera, F.W.M., 2000. Grazing Ecology and Forest History. CABI Publishing., Oxon, UK.
WallisDeVries, M.F., Laca, E.A., Demment, M.W., 1999. The importance of scale of patchiness for selectivity in grazing herbivores. Oecologia 121, 355-363.

Weltzin, J.F., Archer, S., Heitschmidt, R.K., 1997. Small-mammal regulation of vegetation structure in a temperate Savanna. Ecology 78, 751-763. 